\title{
OF WHICH CENTER AND PERIPHERY ARE WE TALKING?
}

\author{
de qual centro e periferia estamos falando? \\ Ralfo Edmundo Matos* \\ Rodrigo Nunes Ferreira **
}

\begin{abstract}
Resumo
Esse estudo tem como objetivo a análise comparada de mudanças nos níveis de ocupação e renda nos mercados de trabalho de regiões metropolitanas (RMs) do Nordeste e Sudeste. Para tanto foram discriminadas as populações de trabalhadores migrantes e não-migrantes residentes nos núcleos e periferias das RMs de Fortaleza e de Recife vis-à-vis os residentes das RMs de São Paulo e do Rio de Janeiro entre 2000 e 2010, segundo classes de renda e estratificação da condição de pobreza e extrema pobreza. Os resultados indicam que houve melhora generalizada das condições de remuneração dos trabalhadores migrante e não-migrante, não obstante a aceleração do processo de urbanização das últimas décadas há evidências de maior inserção ocupacional dos dois grupos populacionais, com a supremacia dos migrantes sobre os não-migrantes em termos de renda mediana auferida no trabalho segundo dados censitários. A perspectiva de que a expansão da ocupação e renda traga benefícios ao padrão habitacional de periferias metropolitanas não deve ser negligenciada em análises subsequentes, que explorem outras características dos domicílios, sobretudo se houver continuidade de ganhos de remuneração sustentados por conjunturas econômicas de crescimento no decorrer da atual década.
\end{abstract}

Palavras-chaves:Migrações internas; Periferias metropolitanas; Pobreza urbana.

\begin{abstract}
This study is a comparative analysis of changes in levels of employment and income in the metropolitan areas of labor markets (RMs) of Northeast and Southeast. The populations of workers were discriminated between migrants and non-migrants, residents in the cores and peripheries of metropolitan areas of Fortaleza and Recife compared with residents of metropolitan regions of São Paulo and Rio de Janeiro between 2000 and 2010, according to the level of income and the condition of poverty or extreme poverty. The results indicate improvement of the remuneration of migrant and non-migrant workers, despite the acceleration of the urbanization of the last decades, there is evidence of higher occupational integration of the two population groups, with the supremacy of migrants on the non-migrants in terms of median income of work according to census data. The perspective that occupation and income expansion might bring benefits to the metropolitan outskirts residence standards should not be neglected in further analysis, which may explore other dwelling features, particularly if an income gain steadiness sustained by growing economic scenarios should be observed along the current decade.
\end{abstract}

Key words: Internal migrations; Metropolitan outskirts; Urban poverty.

\section{Resumen}

Este estudio tiene como objetivo el análisis comparativo de los cambios en los niveles de ocupación y de ingresos en las áreas metropolitanas de los mercados de trabajo (RMS) de Nordeste y Sureste. Para ambos fueron discriminados poblaciones de los trabajadores migrantes y no migrantes residentes en los núcleos y periferias de las áreas metropolitanas de Fortaleza y Recife en comparación con los residentes de las regiones metropolitanas de São Paulo y Río de Janeiro entre 2000 y 2010, de acuerdo con las clases de ingresos y la estratificación de acuerdo la condición de pobreza o extrema pobreza. Los resultados indican una mejora general de las condiciones de remuneración de los trabajadores migrantes y no migrantes. A pesar de la aceleración del proceso de urbanización en décadas hay evidencia de una mayor integración profesional de los dos grupos de la población, con la supremacía de los migrantes sobre los no migrantes en términos de ingresos medios obtenidos en el trabajo de acuerdo a los datos del censo. La perspectiva que la expansión del empleo y los ingresos pueden beneficiarse las viviendas em las periferias metropolitanas no debe ser descuidado en los análisis posteriores que exploran otras características de los hogares, sobre todo si hay continuidad de los beneficios de compensación sostenida por coyunturas de crecimiento económico durante el década actual.

Palabras Claves: Migración interna; Periferias metropolitanas; Pobreza urbana.

(*) Lecturer, Doctor of the Federal University of Minas Gerais (Universidade Federal de Minas Gerais) - Av. Antônio Carlos 6627, CEP: 31270901, Belo Horizonte (MG), Brasil. Tel: (+55 31)34995426 - ralfomatos@gmail.com

(**) Msc. Universidade Federal de Minas Gerais - Av. Antônio Carlos 6627, CEP: 31270901, Belo Horizonte (MG), Brasil. Tel: (+55 31) 34995426 - rodrigonunesferreira@gmail 
MATOS, R. E.; FERREIRA, R. N.

\section{INTRODUCTION}

Life in big cities has been the center of debates around the world for a long time. The last United Nations report on global urban population growth points to a inevitable urbanization of mankind, even in continents suffering from severe poverty or where the population body is not yet expressive (UNITED NATIONS, 2012). The resulting problems from the urbanization hastening we observe in the world today, or that Europe has experienced during the industrial revolution are known and have been described by renowned authors in literature. However, questions regarding urbanization increments still arouse, challenging the work of contemporary analysts.

Martine (2007), for instance, when discussing the environmental issue, observes that in spite a great portion of urban populations being composed by poor people who live in underprivileged conditions at metropolitan outskirts, most of the existing environmental problems are due to a production and consuming model that requires an enormous amount of energy to feed the industry and the transports, and grant reasonable levels of comfort to the population at their homes (heating, lighting and appliances), which in turn generates great quantities of garbage and air pollution.

That put, the author holds a clearly pro-urban view, favoring urban concentration, what could represent a more sustainable land use. He notes that urbanization is inescapable, but it can also be "beneficial from the environmental perspective, given the current demographic and economic reality". Degraded environments in urban areas are more related to the unsustainable development patterns, along with poverty increasing due to the absence of economic opportunities and the lack of urban management, control and planning. One of the land-use planning main goals should count on attending the poor population needs. Imposing barriers to the rural-urban migration, as many governments insist on promoting, remains a worthless effort. "Such attitudes have forced the poor to dwell in marginal, ecologically fragile or dangerous areas, such as river borders and steep hills. This has been contributing to the foulness and misery of the new urban population, as well as to the cities' ecological damaging" (MARTINE, 2007, p. 187). It is not possible to disagree with this statement, especially considering the elitist tradition urban planning has encompassed for over a century.

Martine (2007) has performed a global urbanization analysis from an environmental viewpoint, attempting to reassure the tendencies pointed by the UN in its report (UNITED NATIONS, 2006). Most of his conclusions are unmistakable, although there are relevant specificities when the analysis scope is changed. In countries were the urbanization has reached irreversible high levels, urban planning may actually improve the ambience and life conditions of dense and geographically extended metropolises residents, for example, by implanting diverse vertical nuclear hubs that magnify the traditional urban centers. In countries with a lower level of this urban macrocephaly (such as Brazil) where it is possible to identify hundreds of urban poles landing a huge portion of the urban population, environmental and economic circumstances and advantages are of a different kind, and urban planning may bring to light other discussions over inhabitants' standards and quality of life. Medium-sized equipped cities may favor the economic estimates regarding a series of costs related to population mobility (including their journey from home to work, leisure, or public services and facilities). If excessive absorption of rural areas for urban expansion seems an irrationality from an urban planning standpoint, besides making the presence of miserable and outlying outskirts unavoidable, then one should question if such statements end up injecting a certain degree of 'fatalism', supposedly attested by the mass consumption modern society.

It is undeniable that big cities represent unique human concentrations throughout human history. They bring to life physical and territorial expansions never seen before, from rural areas integrations, 'infinite' urban outskirts, illegitimate and precarious allocations, various types of invasions, besides enclosed, fenced towns, high and middle-income segments fortresses. They spread like a virus, as Henry Lefebvre (1999) would state.

United Nations estimates from 10 years ago indicated the world population living in slums 
had doubled its size in seven years and reached one billion inhabitants in 2003, almost 1/7 of the whole population in the planet. This number was expected to double once more up to 2030 (UN-HABITAT, 2003).

Do the current urban outskirts differ a lot from those in the past? And if so, does this evidence associates with the high number of migrants who do not have a 'precise landing', which expelled from rural areas, transit around the urban territories? In many Africa and Asia regions that seems to be the 21 st century urban outskirts scenario. The population scales are impressive amidst catastrophic poverty levels.

What about Brazil? Despite the country has virtually completed its urban demographic transition - a stage that African countries will only reach in decades to come, do urban expansion disadvantages continue to be dramatic? Motta (2004, p. 136) stated that there was unemployment, underemployment and poverty around the metropolitan outskirts. Data collected by Sônia Rocha showed a 32.1\% participation of metropolitan areas in the total of Brazilian poor population in 1999. Roughly, 17.5 million poor people lived in the 10 main metropolitan regions (RMs). São Paulo RM (RMSP) contributed with over one third of metropolitan poverty, and Rio de Janeiro RM (RMRJ) with $16.7 \%$, while in the RMs of Recife and Fortaleza, smaller areas, there were other $17.7 \%$ of the metropolitan poor population (ROCHA, 2003, p. 127, 196). Based on the 1991 and 2000 demographic censuses, Maricato (2002) concluded that Brazilian shantytowns had augmented in $22 \%$, and in São Paulo only, there was an increase in their number from 585 in 1991 to 612 in 2000.

Do the data from the 2000 and 2010 censuses validate this reality? Even considering the period when there was a life condition improvement for a significant part of the Brazilian population, say, the 30 million individuals who have shifted into the lower extracts of the traditional medium class, called 'new medium class' (SAE, 2012)?

To the economist Wilson Cano, Brazil is still going through a disturbing crisis. In his book, Essays on the Brazilian urban crisis, launched in 2011, the author bares problems due to the hastened urbanization in the country, such as the gaps left in terms of habitational policies, real estate speculation and foreign capital inflows in urban business since the 1990's. Cano understands that the urbanization process in Brazil has yielded positive consequences, but has also risen problems hard to deal with, certainly owing to its speeded form, as well as it has happened in other Latin American countries: among three and four decades, millions of people have moved to cities incapable of providing adequate structures of planning, legislation and management. (CANO, 2011)

In a recent interview, Wilson Cano states that until the 1960's we were living in a 'bearable' urbanization, because the bordering process had not yet assumed the present time dramatic proportions. Dwellers did not use to live so far from their jobs and home construction was not so difficult, in spite of all the existing debts in education, health, water supply, sewage and transportation sectors (UFMG, 2012).

Indeed, there was a time when a noteworthy part of the excluded rural population would be incorporated to the urban economies and the geographical mobility conceded an ascending social mobility. As it seems, in times of financial globalization, such possibilities have befallen further and the poor migrants and their kids' future has become darker. It is as if poverty has reproduced faster inside the distant city fringes during the last two decades. Millions of migrants and non-migrants would be forming a generation of poor people whose children would be completely doomed to poverty, deserted in the big city's distant boundaries (MATOS, 2005).

In the past decades, the urban ambience has exploded and the peripherization has not ceased, as Cano had predicted. The time spent in a journey from home to work has become impracticable, and public transportation is precarious; urban sewage is lamentable, despite the improvements in the water supply system. All of these issues are consequences of urbanization. Wilson Cano is emphatic: "with the bordering process, the conurbation, the metropolization and the arrival of several 
urban agglomerations, problems are no longer local or municipal [...] Difficulties [...] become federal [...] e start depending upon political, institutional, budgetary and fiscal matters" (UFMG, 2012). The urban land question is still critical. The author observes that, since the military habitational policy, by the time the Housing National Bank (BNH) was created, real estate speculation has gained projection. The BNH's logic of exploiting inexpensive lands in urban outskirts was key to the government at the time, and it is still perform by the Minha Casa, Minha Vida program. The costs of carrying infrastructure into these new border areas are extraordinary; besides, speculation related to more equipped urban lands shifts real estate prices into irrational levels.

This paper does not detail nor discuss several of the queries proposed by Cano, Martine and others. Most of the author's assertions are unquestionable. The matter of interest here is to establish a few comparisons amongst dense metropolises holding large outskirts, where the vulnerability of dwellers life conditions could be broadening or not. In fact, this study aims to examine the income level of migrant and non-migrant workers inhabiting nucleuses and borders of four Brazilian metropolitan regions (RMs) between 2000 and 2010. This analysis strikes a deeper discussion about life condition differences in central and marginal areas from distinct metropolises, which goes beyond the limits of the present study. After all, is poverty the same in metropolitan outskirts from RMs regionally and historically separated by inequality?

As for the ascending mobility matter, resulting from labor income surplus, some effort will be placed in order to assess the migrant and non-migrant labor force spatial redistribution (considering as labor force the working population with 15 years of age or older). This admeasurement will be conducted based exclusively on the two last national demographic censuses (2000 and 2010). Methodology consists in distinguishing and comparing: non-migrants; fixed-date immigrants; and return immigrants older than 15 years who were occupied on the censuses dates, by calculating the domiciliary income and individual income median (changed into average income per worked hour); and the stratification of poverty and extreme poverty (according to the Federal Government income transfer programs cut-line limits).

It is evident that old myths about the migrant groups negative presence will be considered, despite Martine's assertions (1980) about migrants positive influence in receptive areas. The antiquated belief that outskirts expansion is usually caused by incessant flows of poor immigrants looking for a job at the big urban centers will be reassessed, in light of recent census data. Have immigrants been contributing to poverty enhancement in big metropolises, both in central and marginal areas; or are they singularly distinct from the other poor non-migrant residents?

2. Residents from four metropolitan areas and occupation and employment levels

To allow comparison, four Brazilian metropolitan regions were selected, considering their distant location from one another as well as social and economic differences: São Paulo and Rio de Janeiro and Fortaleza and Recife. Data refer to all inhabitants aged 15 years or more, residing both in the city core (central municipality) and its outskirts (municipalities composing the metropolitan periphery). The migratory status was discriminated according to the reported fixed-date migration. The non-migrants (people who have not migrated during the five-year period right before the census date) are compared to the people who have moved from their residences during the periods of 1995/2000 (for the 2000 Census) and 2005/2010 (for the 2010 Census), sorting out those who have left and returned to the same city of residence during the respective periods. Disaggregating the called 'return immigrants' allows for a better view to this fraction of migrants, in face of the return migration phenomenon rise in the last decades; plus it ensues an attempt of identifying this migrant's peculiarities.

Before proceeding to comparisons about income and poverty levels, it is important to check these subpopulations' occupational degree in each of the censuses. The premise is that a great deal of the 15 or older population is occupied in economic activities, even though the presence of elder- 
ly citizens and students (therefore unoccupied) should be superior among the non-migrant due to the selection effects in migration (the dominant migrant profile is that of a young adult worker, in search of a job opportunity). In addition, data may have a correlation with the country's economic cycle stage or with the higher dynamism observed in determined region metropolises.

Table 1 allows us to conclude that the occupational level of the analyzed populations is relatively high, usually falling above the $50 \%$ mark. That becomes more evident with the 2010 Census data. Even amid non-migrants, notably less occupied than migrants, the occupational degree has risen in 2010: more in São Paulo RM than in Rio de Janeiro RM; more in Fortaleza RM than in Recife RM. The fixed-date immigrants at the RMSP core surpass the $68 \%$ of occupation in that year, whilst in RJRM this proportion reaches $65.6 \%$. In Fortaleza and Recife such figures are also quite expressive: $61.4 \%$ and $60.1 \%$. The same way, among the return immigrants these numbers equally significant in 2010: 62.1\% in Fortaleza; 58.9\% in Recife; 68.4\% in São Paulo and 59.1\% in Rio. These percentages endorse notified tendencies from 2012, when there was an unmarked situation of full employment in many regions and sub-regions the country . Nevertheless, economic growth witnessed in the Lula government period must have positively influenced the occupation data from Table 1, when both periods - 2000 and 2010 - are compared.

Table 1 - Total number of residents and percentage of occupied people among non-migrant, fixed-date immigrant and return immigrant populations aged 15 years or older, resident in selected metropolises 2000/2010

\begin{tabular}{|c|c|c|c|c|c|c|c|}
\hline \multirow{2}{*}{\multicolumn{2}{|c|}{$\begin{array}{l}\text { Metropolitan Region } \\
\text { Total of Residents }\end{array}$}} & \multicolumn{2}{|c|}{ Non-migrants } & \multicolumn{2}{|c|}{ Fixed-date immigrants } & \multicolumn{2}{|c|}{ Return immigrants } \\
\hline & & $\%$ Occupied & $\begin{array}{c}\text { Total of } \\
\text { Residents }\end{array}$ & $\%$ Occupied & $\begin{array}{c}\text { Total of } \\
\text { Residents }\end{array}$ & $\%$ Occupied & \\
\hline \multicolumn{8}{|c|}{2000 Census } \\
\hline \multirow{2}{*}{ RM Fortaleza } & Core & $1,385,877$ & 51.8 & 105,444 & 54.6 & 20,386 & 57.4 \\
\hline & RM periphery & 502,780 & 47.9 & 82,391 & 48.6 & 8,613 & 51.1 \\
\hline \multirow{2}{*}{ RM Recife } & Core & 981,975 & 47.9 & 57,991 & 52.3 & 10,698 & 53.8 \\
\hline & RM periphery & $1,184,674$ & 42.8 & 152,683 & 47.2 & 23,664 & 47.4 \\
\hline \multirow{2}{*}{$\begin{array}{l}\text { RM Rio de } \\
\text { Janeiro }\end{array}$} & Core & $4,287,383$ & 51.2 & 200,114 & 60.4 & 46,761 & 57.1 \\
\hline & RM periphery & $3,260,268$ & 49.1 & 329,520 & 52.5 & 62,395 & 51.4 \\
\hline \multirow{2}{*}{$\begin{array}{l}\text { RM São } \\
\text { Paulo }\end{array}$} & Core & $7,297,518$ & 55.2 & 464,633 & 61.1 & 79,713 & 60.3 \\
\hline & RM periphery & $4,468,354$ & 52.4 & 750,543 & 55.7 & 95,401 & 56.0 \\
\hline \multicolumn{8}{|c|}{2010 Census } \\
\hline \multirow{2}{*}{ RM Fortaleza } & Core & $1,783,623$ & 58.9 & 89,846 & 61.4 & 24,334 & 62.1 \\
\hline & RM periphery & 759,508 & 52.7 & 79,053 & 56.2 & 14,237 & 55.2 \\
\hline \multirow{2}{*}{ RM Recife } & Core & $1,143,695$ & 53.7 & 59,373 & 60.1 & 13,030 & 58.9 \\
\hline & RM periphery & $1,478,621$ & 49.4 & 134,465 & 54.6 & 26,527 & 53.0 \\
\hline \multirow{2}{*}{$\begin{array}{l}\text { RM Rio de } \\
\text { Janeiro }\end{array}$} & Core & $4,856,124$ & 56.8 & 179,427 & 65.6 & 57,764 & 63.1 \\
\hline & RM periphery & $3,956,703$ & 54.6 & 259,416 & 57.9 & 54,814 & 59.1 \\
\hline \multirow{2}{*}{$\begin{array}{c}\text { RM São } \\
\text { Paulo }\end{array}$} & Core & $8,374,119$ & 61.5 & 421,532 & 68.5 & 120,866 & 68.4 \\
\hline & RM periphery & $5,729,204$ & 60.0 & 612,497 & 65.4 & 104,984 & 64.7 \\
\hline
\end{tabular}

Source: IBGE, Demographic Censuses 2000 and 2010 (sample microdata)

In order to address inhabitant's life conditions from the four metropolises under study, it is necessary to examine the income data, despite all the known problems associated with earning declarations around the world. Therefore, per capita domiciliary income data seem to suit our purposes best, and are analyzed here under the assumption that declaration errors found in both censuses' extended sample are homogeneously distributed in space. Using big figures, such as expressive population contingents, serves as a counterweight to this problem, but it does not solve the riddle of omitted labor earnings when the level of acquired income is, for example, as high as in São Paulo. 
The main conclusions drawn from Table 2 can be summarized as follows:

1. Per capita income at RMSP and RMRJ cores, as expected, are quite superior to those observed in their outskirts and the northeastern metropolises. In 2000, the per capita income among the non-migrants in São Paulo exceeded in 2.4 times the same figure in Fortaleza. In 2010 however, this discrepancy fell into 1.7 (still 70\% greater) .

2. In almost all of the cases, the migrants' per capita income is superior to the non-migrants. In 2000, fixed-date immigrants' earnings went over the non-migrants' in Fortaleza and Recife, ranging from $20 \%$ higher in the Fortaleza's periphery to $109 \%$ in the municipality of Recife. The same was not observed for São Paulo and Rio: migrants' per capita income in those regions is similar or even less than the non-migrants' income (in RMRJ outskirts the immigrants' per capita income is $5 \%$ superior).

3. The 2010 Census data support the higher income levels for migrants, expressly for the northeastern metropolises; however the figures also indicate that fixed-date immigrants obtain a greater income level when compared to non-migrants. In 2010, there is not a single case in which the non-migrants' per capita income exceeds the migrants' income; that has been the case since 2000. The fixed-date immigrants' earnings in Recife's core area was more than double the non-migrants'.

4. As for the return immigrants, it is initially worthy to consider that this group must include several less-qualified workers who have gone back to their hometowns after trying it - and not succeeding - elsewhere. In fact, in 2000 the return immigrants' per capita income is lower than most other migrants' income, with the exception of the ones who returned to either Rio de Janeiro or São Paulo. In 2010 results are even more emphatic: the whole returning population showed inferior income compared to all other migrants.

Table 2 - Median Per capita domiciliary income (in BR\$) of non-migrant, fixed-date immigrant and return immigrant populations aged 15 years or older, resident in se-lected metropolises 2000/2010

Source: IBGE, Demographic Censuses 2000 and 2010 (sample microdata)

\begin{tabular}{c|c|c|c|c|c|c|c}
\hline \multicolumn{2}{c|}{$\begin{array}{c}\text { Metropolitan Region } \\
\text { 2000 }\end{array}$} & \multicolumn{2}{c|}{ Non-migrants } & \multicolumn{2}{c}{ Fixed-date immigrants } & \multicolumn{2}{c}{ Return immigrants } \\
\cline { 3 - 8 } & $\mathbf{2 0 1 0}$ & $\mathbf{2 0 0 0}$ & $\mathbf{2 0 1 0}$ & $\mathbf{2 0 0 0}$ & $\mathbf{2 0 1 0}$ & \\
\hline \multirow{2}{*}{ RM Fortaleza } & Core & 275.83 & 408.00 & 392.92 & 510.00 & 334.37 & 489.00 \\
\cline { 2 - 8 } & RM periphery & 148.33 & 255.00 & 177.80 & 300.00 & 167.32 & 263.33 \\
\hline \multirow{3}{*}{ RM Recife } & Core & 296.65 & 434.50 & 619.94 & 920.00 & 392.92 & 825.00 \\
\cline { 2 - 8 } & RM periphery & 212.57 & 319.60 & 285.85 & 400.00 & 245.57 & 350.00 \\
\hline \multirow{2}{*}{ RM Rio de Janeiro } & Core & 628.67 & 690.00 & 593.31 & 850.00 & 602.48 & 834.00 \\
\hline \multirow{2}{*}{ RM São Paulo } & RM periphery & 357.56 & 485.00 & 376.71 & 550.00 & 353.63 & 500.00 \\
\cline { 2 - 8 } & Core & 653.23 & 700.00 & 522.19 & 749.50 & 530.83 & 666.67 \\
\hline
\end{tabular}

Notes: 2000 earnings fixed by the accumulated INPC from 08/2000 to 07/2010 ( applied adjustment index: 1,9645958; source: BACEN);

If the data from the last two tables are examined as one, may be suggesting that lower occupation levels are associated to inferior earnings, which could reveal situations in which there would be more occupied family members as a strategy to enlarge domiciliary income. That could be the case of migrants from the 1995-2000 period who have returned to the northeastern metropolises (they show higher occupational levels compared to other migrants). But it could also be the case in which median income does not apply to the typical failure instances - when migrants fail the 
attempt of settling in their destinations - as it has happened to the non-peripheral metropolitan areas' residents, who have, all together, achieved median income levels comparable to the other migrants'.

Does data from the last censuses grant us to go beyond when comparing the four metropolises using variables such as income, poverty and peripherization? Before moving forward, we should reexamine the absolute numbers presented in Table 1. Figures indicate that the number of immigrants inhabiting the four metropolitan outskirts has been undergoing few changes, whilst in the two northeastern RMs the records show an increase of return immigrants. Data endures that peripheral expansion might be supported by the non-migrants, mainly in Fortaleza, since in the other RMs the $20 \%$ expansion observed over 10 years may be due to their old borderline municipalities' population intrinsic growth.

We should then inspect if the proportion of poor and extreme poor in the population as a whole has increased. The limits to measuring poverty are known, especially the methods focused on income, for the phenomenon multidimensional aspect is often understated in this kind of approach (SEN, 2001; ALKIRE, FOSTER, 2007). Another problem is the setting of a single poverty cut-line for all of the many diverse Brazilian regions, with different life costs, which can lead to underestimations of the final statistics (ROCHA, 2003). Even so, income is still a respectable indicator in capitalist societies, and it is usually capable of reasonably summarizing poverty and deprivation conditions in urban environments with historical collections of big metropolitan areas' typical services and infrastructures, as in the four cases studied here. In order to simplify comparison, we have decided to analyze results from the last two censuses. Data exposed in Table 3 brings to light part of the questions involving poverty development in the selected metropolitan regions. The most evident conclusions can be abridged in two:

1) The percentage of poor people is more expressive in 2000. In 2010 the number of poor and extreme poor has diminished in virtually all analyzed areas. An exceptional figure must be highlighted: there was an increase in extreme poverty for the Southeast RMs, among both immigrants and non-migrants, notably at the São Paulo and Rio de Janeiro core areas. The poverty percentages, in turn, was barely altered at these same nucleuses.

2) The studied RMs show different results in terms of poverty incidence amongst migrants and non-migrants. In the Northeast selected areas, either in the capitals or in the outskirts, the poor people proportion is bigger for the non-migrant and return immigrant groups, when compared to the fixed-date immigrants. In the Southeast RMs this pattern was inverted in 2000, at what time poverty incidence was greater within the migrant population. In 2010, the relationship took a slight swing, with an upper poverty frequency only among return immigrants, as the fixed-date immigrants displayed the smallest percentages of poverty.

Data evaluation on obtained money from the labor market (Table 4) permits placing clues to clarify the greater reduction of poverty among migrants. To reduce possible impacts over income marks from people of different ages throughout the lifespan, we chose to use the indicator 'median of average income per worked hour' (as it has been done for the migrant/non-migrant comparisons). That way we avoid the effect of shorter work shifts and their lower earnings, a common situation for the young workers or even among women occupied in some tertiary sector activities.

The examined results, contrary to old-fashioned theories and current misperceptions between urban peripherization and migration end up implying that migration may be a factor of poverty percentage reduction, markedly in the selected RMs, historically contrasting regions with regard to economics. 
MATOS, R. E.; FERREIRA, R. N.

Table 3 - Percentage of poverty and Extreme poverty among non-migrant, fixed-date immigrant and return immigrant populations aged 15 years or older, resident in se-lected metropolises 2000/2010

\begin{tabular}{|c|c|c|c|c|c|c|c|}
\hline \multirow{2}{*}{\multicolumn{2}{|c|}{$\begin{array}{c}\text { Metropolitan Region } \\
\text { Extreme Poverty }\end{array}$}} & \multicolumn{2}{|c|}{ Non-migrants } & \multicolumn{2}{|c|}{ Fixed-date immigrants } & \multicolumn{2}{|c|}{ Return immigrants } \\
\hline & & Poverty & $\begin{array}{c}\text { Extreme } \\
\text { Poverty }\end{array}$ & Poverty & $\begin{array}{l}\text { Extreme } \\
\text { Poverty }\end{array}$ & Poverty & \\
\hline \multicolumn{8}{|c|}{2000 Census } \\
\hline \multirow{2}{*}{ RM Fortaleza } & Core & 8.9 & 24.1 & 5.6 & 17.6 & 7.9 & 19.5 \\
\hline & RM periphery & 20.0 & 45.4 & 15.8 & 39.5 & 17.1 & 42.0 \\
\hline \multirow{2}{*}{ RM Recife } & Core & 8.9 & 23.0 & 5.6 & 14.4 & 6.9 & 20.0 \\
\hline & RM periphery & 13.2 & 32.1 & 10.5 & 24.9 & 13.3 & 29.3 \\
\hline \multirow{2}{*}{$\begin{array}{l}\text { RM Rio de } \\
\text { Janeiro }\end{array}$} & Core & 3.7 & 8.4 & 4.2 & 9.0 & 4.6 & 9.7 \\
\hline & RM periphery & 6.7 & 15.6 & 7.1 & 16.0 & 8.3 & 18.2 \\
\hline \multirow{2}{*}{$\begin{array}{c}\text { RM São } \\
\text { Paulo }\end{array}$} & Core & 3.9 & 7.7 & 4.6 & 9.4 & 5.4 & 10.3 \\
\hline & $\mathrm{RM}$ periphery & 5.4 & 11.0 & 6.9 & 13.6 & 7.5 & 13.9 \\
\hline \multicolumn{8}{|c|}{2010 Census } \\
\hline \multirow{2}{*}{ RM Fortaleza } & Core & 6.1 & 12.7 & 4.6 & 8.4 & 7.7 & 12.1 \\
\hline & RM periphery & 9.7 & 23.1 & 7.5 & 18.2 & 7.8 & 19.4 \\
\hline \multirow{2}{*}{ RM Recife } & Core & 7.0 & 13.7 & 5.1 & 7.4 & 6.6 & 10.9 \\
\hline & RM periphery & 9.2 & 19.0 & 7.2 & 14.1 & 9.4 & 18.5 \\
\hline \multirow{2}{*}{$\begin{array}{l}\text { RM Rio de } \\
\text { Janeiro }\end{array}$} & Core & 5.7 & 8.2 & 5.3 & 7.5 & 7.4 & 9.1 \\
\hline & RM periphery & 6.9 & 11.3 & 5.9 & 9.7 & 5.6 & 11.1 \\
\hline \multirow{2}{*}{$\begin{array}{c}\text { RM São } \\
\text { Paulo }\end{array}$} & Core & 6.6 & 8.9 & 6.7 & 8.5 & 7.6 & 9.6 \\
\hline & RM periphery & 5.7 & 8.6 & 5.0 & 7.9 & 5.6 & 9.4 \\
\hline
\end{tabular}

Source: IBGE, Demographic Censuses 2000 and 2010 (sample microdata)

Notes: 1 - Cut-line categories: Extreme poverty - \% of people with a per capita domiciliary income ranging from R\$0,01 e R\$ 70,00; Poverty - - \% of people with a per capita domiciliary income ranging from R\$0,01 e R\$140,00; 2 - 2000 earnings were fixed by the accumulated INPC from 08/2000 to 07/2010 (applied adjustment index: 1,9645958; source: BACEN

But what could be the explanation for the registered differences between RMs in Northeast and Southeast? Would it be the greater insertion on the migrating population in the labor market - and, as a consequence, their attained income - theses differences' underlying factor?

The expected urban and regional differences prevail amid migrants and non-migrants: the median of income per worked hour assumes upper values in the Southeast region and in the capitals. However, the impressive relative variation of the median income within the fixed-date immigrants in the Recife RM core (144.3\% from 2000 to 2010) means the median income for this group in 2010 outpaces the value recorded for the Southeastern capitals. A similar occurrence takes place among return migrants getting back to Pernambuco (capital of Recife), which similarly to Rio de Janeiro, would be computing the greatest median income for this group in all analyzed areas - 20\% superior to the registered value for Sao Paulo.

Considering disparities between core and periphery, the large Southeast RMs' capitals expressed, in 2000, higher income median values for non-migrants; and nearer values for migrants and non-migrants in the borderline municipalities. In 2010, there is an inversion in Rio de Janeiro; immigrants' median income per hour worked overtakes non-migrants' figures. Whereas in São Paulo there is still a predominance of greater earnings among non-migrants, the differential between groups showed a significant reduction in the studied period: the gap between median income values for non-migrants and fixed-date immigrants was downgraded from $50 \%$ in 2000 to $10 \% 20$ 
10. At the RMs outskirts a positive variation favors immigrants in Rio de Janeiro, while at the São Paulo's metropolitan borders, the differences were reduced between non-migrants and migrants. Between non-migrants and fixed-date migrants the observed income behavior was nearly the same.

Analysis of these same differentials between core and periphery in the Northeast RMs reveals two distinct designs: in the Recife RM the migrant population presents superior income values (as previously underlined). The opposite happens in the Fortaleza RM, where the non-migrant population showed, in both periods, upper median values compared to the capital immigrants; and almost equal figures at the outskirts in 2010.

Table 4 - Median of average income (BR\$) per worked hour in main job for non-migrant, fixed-date immigrant and return immigrant populations aged 15 years or older, resident in selected metropolises 2000/2010.

\begin{tabular}{|c|c|c|c|c|c|c|c|c|c|c|}
\hline \multicolumn{2}{|c|}{ Metropolitan Region } & \multicolumn{3}{|c|}{ Non-migrants } & \multicolumn{3}{|c|}{ Fixed-date immigrants } & \multicolumn{3}{|c|}{ Return immigrants } \\
\hline \multicolumn{2}{|c|}{2000} & 2010 & $\begin{array}{l}\text { Varia- } \\
\text { tion } \%\end{array}$ & 2000 & 2010 & $\begin{array}{l}\text { Varia- } \\
\text { tion } \%\end{array}$ & 2000 & 2010 & $\begin{array}{l}\text { Varia- } \\
\text { tion } \%\end{array}$ & \\
\hline \multirow{2}{*}{ RM Fortaleza } & Core & 3.07 & 4.06 & 32.3 & 2.63 & 3.75 & 42.5 & 2.55 & 3.50 & 37.0 \\
\hline & RM periphery & 1.99 & 3.19 & 60.1 & 2.29 & 3.19 & 39.1 & 2.15 & 3.19 & 48.3 \\
\hline \multirow{2}{*}{ RM Recife } & Core & 3.41 & 4.55 & 33.3 & 4.91 & 8.68 & 76.7 & 3.07 & 7.50 & 144.3 \\
\hline & RM periphery & 2.81 & 3.65 & 29.9 & 3.27 & 4.25 & 29.8 & 3.07 & 3.81 & 24.2 \\
\hline \multirow{2}{*}{$\begin{array}{l}\text { RM Rio de } \\
\text { Janeiro }\end{array}$} & Core & 6.01 & 6.38 & 6.1 & 4.09 & 6.67 & 62.9 & 4.91 & 7.50 & 52.7 \\
\hline & RM periphery & 4.09 & 5.00 & 22.2 & 4.09 & 5.63 & 37.4 & 4.09 & 5.31 & 29.8 \\
\hline \multirow{2}{*}{$\begin{array}{c}\text { RM São } \\
\text { Paulo }\end{array}$} & Core & 6.70 & 6.88 & 2.7 & 4.46 & 6.25 & 40.0 & 5.12 & 6.25 & 22.2 \\
\hline & RM periphery & 5.36 & 5.63 & 5.0 & 4.91 & 5.63 & 14.5 & 4.91 & 5.36 & 9.1 \\
\hline
\end{tabular}

Source: IBGE, Demographic Censuses 2000 and 2010 (sample microdata)

Notes: 2000 earnings fixed by the accumulated INPC from 08/2000 to 07/2010 (applied adjustment index:

1,9645958; source: BACEN); People with zero income from main job were not considering in calculations.

Lastly, it is valuable highlighting that the percentage variation of median average income between 2000 and 2010 for migrants and non-migrants displays a pattern worth investigating in further researches. All of the groups have shown positive variations between 2000 and 2010. Aside from Fortaleza RM outskirts, in all remaining areas both types of migrants have experienced superior changes in their income, compared to non-migrants. Substantially positive variations were perceived in Recife and Rio de Janeiro RMs. Additionally, it is earnest to emphasize that these findings point to a wide-ranging income growth in the core areas, contrasted to the peripheral areas.

Data from Table 4 suggest that labor markets in metropolitan areas outside Southeast have been working as a means to reduce poverty and regional and intrametropolitan income inequalities, as seen between 2000 and 2010 .

\section{FINAL CONSIDERATIONS}

The relationship between urban outskirts expansion and migration no longer holds the obvious empiric evidence from the 1960 and 1970 decades, when the two main metropolitan regions in Brazil would attract massive amounts of workers expelled from the Northeast rural areas. The urban transition, in addition to the demographic transition have become essential elements in economic analysis, remarkably when the GDP growth is discussed in terms of a low productivity recent past, with a rising labor offer and the existing idleness in productive establishments (following many years of economic activity decline). This workforce offer seems to be in extinction; and the migrant worker, despite multiple origins in their migration movements, poses as a experienced professional in central and borderline areas' labor markets from metropolitan regions in the country. 
The hastened urbanization from the last decades has produced material vulnerabilities in many Brazilian metropolitan outskirts. Therefore, it yet evident the lack of basic social infrastructure and urban regulation, and the dwellings transitory aspect at those areas is still alarming. Contradictorily, however, data has begun to outline an improvement in relation to the working population income and employment, what could, in a while, contribute to the alleviation of our repulsive looking urban borders. Data worked here appear to strengthen this perspective, in the same way of the questions presented at the Introduction section final portion.

It can be concluded that the either migrant or non-migrant over 15 years of age group, the occupation level is reasonably high, especially in 2010. The fixed-date immigrants showed a superior occupation in São Paulo RM, although in RMRJ their proportion was almost 66\%. The economic growth observed between 2000 and 2010 must have positively affected the results in favor of the examined migrants and non-migrants.

Data about income obtained in the labor market have aided the comprehension of poverty reduction among migrants. The indicator 'median of average income per worked hour' has evidenced the superiority of median values in Southeast region and capitals for the migrant and non-migrant populations, although the median income percentage variation is too high for the fixed-date immigrants in the Recife RM in 2000 and 2010.

Some of the investments that took place in the Northeast region, and in particular in Recife have drawn qualified migrants from other country regions, and that has caused positive effects over other economic activities, both at the outskirts and at the metropolitan core. This process maintenance was expected, at least until the end of the current decade, in face of the infrastructure works agenda in the region. It is arduous to say if such economic dynamism would be sufficiently virtuous in order to generate new regional self-sustained centers during the next decades. Migration, combined with the pursuit of better occupational placing opportunities seems to be a relevant fact to consider when explaining inequality reduction.

However, the economic and political crisis circumstances that have later been observed in the country, notably from 2014; the interruption of many infrastructure works; and the government budget restraints are factors that could have an impact over these same metropolitan areas due to unemployment rise and advance of several types of poverty. Should the crisis and recession scenario continue to last, observed inequality reduction related gains during the first decade of the $21 \mathrm{st}$ century could even disappear.

\section{BIBLIOGRAPHIC REFERENCE}

ALKIRE, S., FOSTER, J. E. Counting and Multidimensional Poverty Measurement, OPHI Working Paper 7, Oxford Poverty and Human Development Initiative, 2007.

CANO, Wilson. Ensaios sobre a crise urbana do Brasil. Campinas, SP: Editora da Unicamp, 2011. CORRÊA, R. L. Região e Organização Espacial. São Paulo: Ed Ática, 1986.

GOMES, Paulo Cesar da Costa. O conceito de região e sua discussão. In: Geografia: conceitos e temas. Rio de Janeiro: Bertrand Brasil, p. 49-76, 1995.

GRIGG, D. Regiões, modelos e classes. Bol. Geogr. Rio de Janeiro, 32 (234): 3-46, maio/junho, 1973.

HAESBAERT, Rogério. Regional-Global: dilemas da região e da regionalização na geografia contemporânea. Rio de Janeiro: Bertrand Brasil, 2010.

IBGE - Instituto Brasileiro de Geografia e Estatística. Estudos e tratamento da variável rendimento no Censo Demográfico 2010. [Em linha] Rio de Janeiro: IBGE, 2012. Disponível em: ftp://ftp.ibge.gov.br/ Censos/Censo_Demografico_2010/Resultados_Gerais_da_Amostra/Estudo_e_tratamento_rendimentos.pdf [Consult. 13 de novembro de 2012].

IPEA; IBGE; UNICAMP, IPARDES; NESUR, IPARDES. Caracterização e tendências da rede urbana do Brasil. Campinas: Unicamp: IPEA, 1999. 
LEFEBVRE, H. A revolução urbana. Belo Horizonte: Editora UFMG, 1999.

MARICATO, E. Brasil, cidades; alternativas para a crise urbana. Petrópolis: Vozes, 2002.

MARTINE, G. Adaptação dos migrantes ou sobrevivência dos mais fortes? In: MOURA, H. (org.) Migração Interna - textos selecionados, Fortaleza-CE, Banco do Nordeste do Brasil S.A., 1980.

MARTINE, G. O lugar do espaço na equação população/meio ambiente Revista Brasileira de Estudos Populacionais, São Paulo, v. 24, n. n. 2, p. 181-190, 2007.

MATOS, R. Periferias de grandes cidades e movimentos populacionais. Cadernos Metrópole, Rio de Janeiro, n. 13. Pp. 71-105, 2005.

MOTA, D. M. As metrópoles e os desafios da política urbana. In: RIBEIRO, L. C. Q. (org.). Metrópoles; entre a coesão e a fragmentação, a cooperação e o conflito. São Paulo e Rio de Janeiro, FASE, Perseu Abramo. Observatório das Metrópoles, 2004.

RAFFESTIN, Claude. Por uma Geografia do poder. São Paulo: Ática, 1993.

RIBEIRO, A. C. T. . Regionalização: fato e ferramenta. In: Ester Limonad; Rogério Haesbaert; Ruy Moreira. (Org.). Brasil século XXI: por uma nova regionalização? (agentes, processos e escalas). Rio de Janeiro: Max Limonad, 2004.

ROCHA, Sonia. Pobreza no Brasil: afinal, de que se trata?, Rio de Janeiro, Editora FGV, 2003.

ROCHEFORT, Michel. Regionalização e rede urbana. R. RA'E GA. Curitiba, n.7, p.115-121, 2003. Editora UFPR.

SAE - Secretaria de Assuntos Estratégicos. Classe Média em Números. 2012[Em linha] Brasília: SAE Disponível em: http://sae.gov.br/novaclassemedia/numeros/ [Consult. 13 de novembro de 2012].

SEN, Amartya. Desigualdade Reexaminada. Rio de Janeiro: Record, 2001.

UFMG Notícias. Urbanização acelerada explodiu ambiência, avalia economista da Unicamp. [Em linha] Belo Horizonte: UFMG, Disponível em: https://www.ufmg.br/online/arquivos/025733.shtml [Consult. 13 de novembro de 2012].

UN-HABITAT - United Nations Human Settlements Programme. The challenge of slums global report on human settlements 2003, Nairobi-Kenya, UN-Habitat, 2003.

UNITED NATIONS. World Urbanization Prospects: The 2005 Revision. New York: Population Division, Department of Economic and Social Affairs, United Nations, 2006.

UNITED NATIONS. World Urbanization Prospects: The 2011 Revision. New York: Population Division, Department of Economic and Social Affairs, United Nations, 2012.

Submitted september 2015

Accepted november 2015 